\title{
Gambaran Penyakit Jantung Bawaan di Neonatal Intensive Care Unit RSUP Prof. Dr. R. D. Kandou Manado Periode 2013 - 2017
}

\author{
${ }^{1}$ Berry R. Manopo \\ ${ }^{2}$ Erling D. Kaunang \\ ${ }^{2}$ Adrian Umboh
}

\author{
${ }^{1}$ Program Studi Pendidikan Dokter Fakultas Kedokteran Universitas Sam Ratulangi Manado \\ ${ }^{2}$ Bagian Ilmu Kesehatan Anak Fakultas Kedokteran Universitas Sam Ratulangi Manado \\ Email: berryricardomanopo@yahoo.com
}

\begin{abstract}
Congenital heart disease (CHD) is a structural heart defect that results from abnormal embryological heart development, or persistence of some parts of the fetal circulation at birth. Congenital heart disease is divided into two categories, namely noncyanotic congenital heart disease and cyanotic congenital heart disease. Congenital heart disease is caused by interactions between predisposing exogenous factors and endogenous factors. This study was aimed to obtain the profile of CHD in the Neonatal Intensive Care Unit (NICU) of Prof. Dr. R. D. Kandou Hospital Manado in the period 2013 - 2017. This was a retrospective descriptive study using medical record data of patients suffering from CHD in NICU from 2013 to 2017. The results showed that there were 27 patients suffering from CHD consisting of 24 non-cyanotic CHD patients (88.89\%) and 3 cyanotic CHD patients (11.11\%), and the highest incidence was Atrial Septal Defect (ASD) as many as 17 babies (62.96\%). Congenital heart disease was more common in males as many as 18 babies $(66.67 \%)$. In this study, the clinical symptoms oftenly found was shortness of breath $(48.15 \%)$ and the most common diagnosis was pneumonia $(48.15 \%)$. Conclusion: The most common CHD was noncyanotic CHD. The most commonly found defect was ASD. Clinical symptoms that often arised was shortness of breath, pneumonia was the most common comorbid diagnosis, and the dominant gender of CHD was male.
\end{abstract}

Keywords: non-cyanotic CHD, cyanotic CHD, atrial septal defect

\begin{abstract}
Abstrak: Penyakit jantung bawaan (PJB) merupakan defek jantung struktural yang terjadi akibat perkembangan jantung embriologis yang abnormal, atau persistensi dari beberapa bagian dari sirkulasi fetus saat lahir. Penyakit ini dibagi menjadi dua kategori yaitu penyakit jantung bawaan non sianosis dan yang sianosis. Penyakit jantung bawaan disebabkan oleh interaksi antara predisposisi faktor eksogen dan faktor endogen. Penelitian ini bertujuan untuk mendapatkan gambaran penyakit jantung bawaan di Neonatal Intensive Care Unit (NICU) RSUP Prof. Dr. R. D. Kandou Manado periode 2013-2017. Jenis penelitian ialah deskriptif retrospektif dengan menggunakan data rekam medik pasien yang menyandang penyakit jantung bawaan di NICU periode 2013-2017. Hasil penelitian mendapatkan dari 27 pasien dengan PJB, ditemukan PJB non sianotik berjumlah 24 bayi $(88,89 \%)$ dan PJB sianotik berjumlah 3 bayi $(11,11 \%)$ dengan angka kejadian terbanyak pada atrial septal defek (ASD) berjumlah 17 bayi $(62,96 \%)$. Penyakit jantung bawaan paling banyak terjadi pada bayi yang berjenis kelamin laki-laki yaitu berjumlah 18 bayi $(66,67 \%)$. Gejala klinis yang sering muncul ialah sesak napas $(48,15 \%)$ dan diagnosis penyerta terbanyak yaitu pnemonia $(48,15 \%)$. Simpulan: Penyakit jantung bawaan non sianosis merupakan diagnosis terbanyak, jenis ASD, dengan gejala klinis yang sering muncul yaitu sesak napas. Pneumonia merupakan diagnosis penyerta terbanyak. PJB tersering pada jenis kelamin laki-laki.
\end{abstract}

Kata kunci: PJB sianotik, PJB, non sianotik, atrial septal defek 
Dewasa ini perkembangan penyakit non infeksius semakin meningkat, hal tersebut dikarenakan perubahan gaya hidup dan tingkat sosial ekonomi yang mengubah pola munculnya penyakit. Penyakit non infeksius seperti penyakit kongenital saat ini semakin dikenal. Penyakit jantung dan pembuluh darah di Indonesia kini semakin meningkat dan menyebabkan kecacatan bahkan kematian. ${ }^{1}$ Penyakit jantung bawaan (PJB) atau defek jantung bawaan merupakan kelainan struktur jantung dan pembuluh darah yang muncul sejak lahir dan menjadi penyebab utama kematian anak dari semua kelainan bawaan. ${ }^{2}$

Secara umum PJB di negara maju maupun negara berkembang sekitar 6-10 kejadian dari 1000 kelahiran, dengan rerata persentase sekitar 8 anak setiap 1000 kelahiran hidup. ${ }^{3}$ Prevalensi PJB di Eropa akhir-akhir ini dilaporkan oleh 2 makalah utama, dari data pusat untuk 29 populasi di 16 Negara menunjukkan prevalensi 8 per 1000 kejadian. Diperkirakan di Eropa, sekitar 3600 anak lahir dengan PJB dan 3000 meninggal dikarenakan PJB. Di Indonesia sendiri terdapat sekitar 40.000 sampai 50.000 bayi lahir dengan cacat jantung bawaan. ${ }^{4}$ Menurut Perimpunan Dokter Spesialis Kardiovaskular Indonesia (PERKI), penyakit jantung menempati peringkat pertama dari semua penyakit yang menyerang bayi. ${ }^{5}$ Pada penelitian sebelumnya di Bagian Ilmu Kesehatan Anak RSUP Prof. Dr. R. D. Kandou Manado sepanjang tahun 2009-2013 didapatkan dari 53 anak, dengan 34 anak berjenis kelamin laki-laki dan 19 anak berjenis kelamin perempuan, usia 1-6 tahun merupakan penderita terbanyak, dengan jenis PJB yang paling banyak diderita ialah jenis Atrial Septal Defect (ASD) yaitu 34,0\%, diikuti oleh Ventricle Septal Defect (VSD) $28,3 \%{ }^{6}$

Penyakit jantung bawaan dibagi menjadi dua kelompok yaitu PJB dan PJB non sianotik (asianotik). PJB sianotik merupakan penyakit jantung pada anak yang ditandai dengan adanya sianosis sentral dikarenakan adanya pirau dari kiri ke kanan sedangkan PJB asianotik pada anak tidak ditandai dengan sianosis dan memiliki kebocoran pada sekat jantung disertai dengan adanya pirau atau tidak. Contoh dari pada PJB sianotik ialah tetralogi Fallot (TOF), transposisi arteri besar, dan atresia trikuspid, sedangkan contoh PJB asianotik ialah defek septum ventrikel, defek septum atrium, atau tetap terbukanya pembuluh darah seperti seperti pada duktus arteriosus persisten.

Penyakit jantung bawaan sangat sulit untuk dideteksi, hanya sekitar $30 \%$ bayi dengan gejala yang timbul pada minggu pertama dan sekitar $30 \%$ pada masa neonatal yang dapat menyebabkan kematian pada minggu-minggu pertama apabila tidak terdeteksi dan ditangani sedini mungkin. ${ }^{8}$ Anamnesis perlu dilakukan sejak sebelum bayi lahir karena kebanyakan anomali terjadi sejak bulan keenam kehidupan intrauterin, yang mungkin menjadi bayi yang lahir hidup. ${ }^{9}$

Neonatal Intensive Care Unit (NICU) adalah suatu unit yang melakukan perawatan intensif pada bayi yang baru lahir, yang memiliki masalah seperti berat badan lahir rendah, pernapasan yang kurang sempurna, bayi lahir prematur, bayi yang mengalami kesulitan saat lahir, bayi yang memiliki kelainan jantung, dan memiliki gejala dan tanda yang mengkhawatirkan sehingga membutuhkan perawatan atau perlakuan khusus. ${ }^{10}$ Bayi yang dirawat di NICU ialah bayi neonatus yang baru lahir hingga 4 minggu awal kehidupan, yang memiliki kelainan-kelainan bawaan dan penyakit tertentu sehingga memerlukan perawatan intensif agar bayi tetap hidup. ${ }^{11}$

Penelitian ini bertujuan untuk mendapatkan gambaran bayi yang didiagnosis PJB di NICU Bagian Ilmu Kesehatan Anak RSUP Prof. R. D. Kandou Manado periode 2013-2017.

\section{METODE PENELITIAN}

Jenis penelitian ini ialah deskriptif retrospektif dengan desain potong lintang untuk mendapatkan gambaran PJB di NICU RSUP Prof. Dr. R. D. Kandou Manado periode 2013-2017. Populasi penelitian ialah data rekam medik pasien yang 
menderita PJB di NICU RSUP Prof. Dr. R. D. Kandou Manado dari 1 Januari 2013 sampai dengan 31 Desember 2017. Pengambilan sampel penelitian ini menggunakan teknik total sampling. Data yang diambil merupakan data terakhir kontrol pasien.

\section{HASIL PENELITIAN}

Penelitian ini menampilkan kejadian PJB di NICU RSUP Prof. Dr. R. D. Kandou Manado dari tahun 2013 hingga 2017. Dari hasil penelitian didapatkan 27 pasien yang dirawat dengan diagnosis PJB baik sianotik maupun non sianotik.

Distribusi frekuensi berdasarkan tahun memperlihatkan tahun 2013 sebanyak 640 bayi neonatus yang dirawat di NICU dan yang menderita PJB berjumlah 5 bayi (0,78\%); tahun 2014 sebanyak 596 bayi neonatus yang dirawat di NICU, dan yang menderita PJB berjumlah 5 bayi $(0,67 \%)$; tahun 2015 sebanyak 412 bayi neonatus yang dirawat di NICU dan yang menderita PJB berjumlah 9 bayi (2,18\%); tahun 2016 sebanyak 440 bayi neonatus yang dirawat di NICU dan yang menderita PJB berjumlah 6 bayi (1,59\%); dan pada tahun 2017 sebanyak 304 bayi neonatus yang dirawat di NICU dan yang menderita PJB berjumlah 2 bayi $(0,66 \%)$ (Gambar 1$)$.

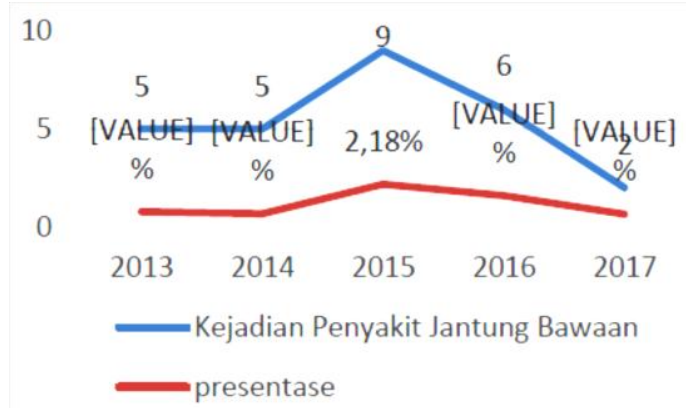

Gambar 1. Distribusi PJB pada bayi berdasarkan tahun

Pada distribusi sampel menurut jenis kelamin didapatkan 18 bayi dengan jenis kelamin laki-laki $(66,67 \%)$ dan 9 bayi dengan jenis kelamin perempuan $(33,33 \%)$ dari total 27 kasus PJB pada bayi di NICU.

Dari hasil penelitian didapatkan bayi yang menderita PJB non sianotik berjumlah
24 bayi $(88,89 \%)$ dan PJB sianotik berjumlah 3 bayi $(11,11 \%)$.

Tabel 1 menampilkan jenis PJB dengan bayi yang menderita ASD berjumlah 17 bayi $(62,96 \%)$, VSD berjumlah 6 bayi $(22,22 \%)$, TOF berjumlah 2 bayi $(7,41 \%)$, transposition of great arteries (TAG) berjumlah 1 bayi $(3,70 \%)$, dan ASD disertai VSD berjumlah 1 bayi $(3,70 \%)$.

Tabel 1. Jenis penyakit jantung bawaan

\begin{tabular}{ccc}
\hline Variabel & Jumlah & \% \\
\hline ASD & 17 & 62,96 \\
VSD & 6 & 22,22 \\
TOF & 2 & 7,41 \\
TAG & 1 & 3,70 \\
ASD + VSD & 1 & 3,70 \\
Total & 27 & 100 \\
\hline
\end{tabular}

Dari data rekam medis yang diambil terdapat beberapa penyakit penyerta bersamaan dengan PJB pada bayi neonatus yaitu: pnemonia $(48,15 \%)$, sepsis $(37,04 \%)$, dekompensatio cordis $(18,52 \%)$, gagal napas (14,81\%), hiperbilirubinemia $(14,81 \%)$, post colostomi ec. atresia ani $(7,41 \%)$, gawat napas $(3,70 \%)$, prematur $(3,70 \%)$, kejang $(3,70 \%)$, blefarokonjungtivitis $\quad(3,70 \%)$, mesocardia $(3,70 \%)$, caput succedaneum $(3,70 \%)$, paresis $n$. brachialis $(3,70 \%)$, lesi upper plexus brachialis (3,70\%), hipoalbuminemia $(3,70 \%)$, MAS $(3,70 \%)$, TI ringan $(3,70 \%)$, post ileostomy ec. atresia ani $(3,70 \%)$, kolestasis $(3,70 \%)$, HMD $(3,70 \%)$, hipoglikemia $(3,70 \%)$, syok septik $(3,70 \%)$, pulmonal stenosis $(3,70 \%)$, Erb's paralisis $(3,70 \%)$, hiponatremia $(3,70 \%)$, bronchopulmonary dysplasia $(3,70 \%)$, candidiasis oral $(3,70 \%)$, dan BBLR (3,70\%) (Tabel 2).

Dari 27 bayi neonatus dirawat di NICU yang menderita PJB dengan penyakit penyerta, didapatkan status kepulangan dengan persentase sembuh penyakit penyerta berjumlah 22 bayi $(81,48 \%)$ dan yang meninggal berjumlah 5 bayi $(18,52 \%)$.

Tabel 3 memperlihatkan distribusi sampel menurut gejala klinis yang menunjukkan bahwa dari 27 bayi yang menderita PJB, gejala klinis yang ditemukan ialah sesak napas $(48,15 \%)$, demam $(37,04 \%)$, 
napas cepat $(22,22 \%)$, kebiruan $(22,22 \%)$, kekuningan $(11,11 \%)$, muntah $(7,41 \%)$, perut kembung $(7,41 \%)$, kelumpuhan ekstremitas (7,41\%), kejang (3,70\%), berlendir $(3,70 \%)$, merintih $(3,70 \%)$, tidak sadar $(3,70 \%)$, kelemahan $(3,70 \%)$, BAB cair $(3,70 \%)$.

Tabel 2. Distribusi diagnosis penyerta

\begin{tabular}{lcc}
\hline Diagnosis penyerta & Jumlah & $\mathbf{\%}$ \\
\hline Pneumonia & 15 & 48,15 \\
Sepsis & 10 & 37,04 \\
Decompensatio & 5 & 18,52 \\
cordis & & \\
Gagal napas & 4 & 14,81 \\
Hiperbilirubunemia & 4 & 7,41 \\
Post colostomi ec & 2 & 3,70 \\
atresia ani & & \\
Gawat napas & 1 & 3,70 \\
Prematur & 1 & 3,70 \\
Kejang & 1 & 3,70 \\
Blefarokonjungtivitis & 1 & 3,70 \\
Mesocardia & 1 & 3,70 \\
Caput succedaneum & 1 & 3,70 \\
Paresis n. Brachialis & 1 & 3,70 \\
Lesi upper plexus & 1 & 3,70 \\
brachialis & & \\
Hipoalbuminemia & 1 & 3,70 \\
MAS & 1 & 3,70 \\
TI ringan & 1 & 3,70 \\
Post ileostomi ec & 1 & 3,70 \\
atresia ani & & \\
Kolestasis & 1 & 3,70 \\
HMD & 1 & 3,70 \\
Hipoglikemia & 1 & 3,70 \\
Syok septik & 1 & 3,70 \\
Pulmonal stenosis & 1 & 3,70 \\
Erb's paralkysis & 1 & 3,70 \\
Hiponatremia & 1 & 3,70 \\
Bronchopulmonary & 1 & 3,70 \\
dysplasia & & \\
Candidiasis oral & 1 & 3,70 \\
BBLR & 1 & 3,70 \\
\hline & & \\
\hline
\end{tabular}

Tabel 3. Distribusi gejala klinis

\begin{tabular}{lcc}
\hline \multicolumn{1}{c}{ Gejala klinis } & Jumlah & $\mathbf{\%}$ \\
\hline Sesak napas & 13 & 48,15 \\
Demam & 10 & 37,04 \\
Napas cepat & 6 & 22,22 \\
Kebiruan & 6 & 22,22 \\
\hline
\end{tabular}

\begin{tabular}{lll}
\hline Kekuningan & 3 & 11,11 \\
Muntah & 2 & 7,41 \\
Perut kembung & 2 & 7,41 \\
Kelumpuhan & 2 & 7,41 \\
ekstremitas & & \\
Kejang & 1 & 3,70 \\
Berlendir & 1 & 3,70 \\
Merintih & 1 & 3,70 \\
Tidak sadar & 1 & 3,70 \\
Kelemahan & 1 & 3,70 \\
BAB cair & 1 & 3,70 \\
\hline
\end{tabular}

\section{BAHASAN}

Bayi yang menderita PJB yang dirawat di NICU RSUP Prof. Dr. R. D. Kandou Manado selama tahun 2013-2017 sebanyak 31 pasien dan hanya 27 pasien yang memenuhi kriteria inklusi penelitian ini. Empat rekam medik lainnya tidak ditemukan oleh karena sudah terlalu lama atau telah hilang sehingga tidak dapat menentukan jenis PJB. Kejadian PJB paling banyak terdapat pada tahun 2015 berjumlah 9 bayi neonatus, diikuti tahun 2016 bejumlah 6 bayi neonatus, 2013 berjumlah 5 bayi neonatus, 2014 bejumlah 5 bayi neonatus dan 2017 berjumlah 2 bayi neonatus.

Berdasarkan jenis kelamin, PJB paling sering ditemukan pada bayi laki-laki $(66,67 \%)$ dibandingkan pada bayi perempuan $(33,33 \%)$. Hasi penelitian ini sejalan dengan yang dilaporkan oleh Hermawan et al. ${ }^{12}$ di RSUP Dr. M. Djamil Padang pada periode Januari 2013-Desember 2015 yang mendapatkan 85 anak penderita PJB dengan 46 anak berjenis kelamin laki-laki dan 39 anak berjenis kelamin perempuan.

Dari 27 sampel yang didapat, ditemukan 24 bayi neonatus menderita PJB non sianotik dan 3 bayi neonatus menderita PJB sianotik. Jenis yang paling banyak yaitu ASD (62,96\%), diikuti dengan VSD $(22,22 \%)$, TOF $(7,41 \%)$, TAG $(3,70 \%)$, dan ASD disertai VSD (3,70\%). Hasil tersebut tidak jauh berbeda dengan penelitian Liu et al. ${ }^{13}$ yang melaporkan bahwa VSD (29\%), ASD (21\%), dan PDA (14\%) merupakan lesi terbanyak.

Pada status kepulangan didapatkan sebanyak 5 bayi meninggal dunia $(18,52 \%)$ 
dan 22 bayi sembuh $(81,48 \%)$ dengan beberapa persyaratan yaitu ada yang sembuh total dan ada yang perlu untuk melakukan kontrol kembali di poliklinik bila ditemukan gejala-gejala seperti demam, sesak napas dan sianosis.

Pada penelitian ini, gejala klinis berupa sesak napas, demam, napas cepat, kebiruan, kekuningan, muntah, perut kembung, pembengkakan ekstremitas, kejang, merintih, tidak sadar, kelemahan, dan berlendir ditemukan bervariasi karena PJB itu sendiri atau oleh karena penyakit penyerta lainnya. Kinsey dan White ${ }^{14}$ menyatakan bahwa gagal jantung secara langsung dapat menyebabkan terjadinya demam oleh karena peningkatan metabolisme, walaupun kebanyakan demam disebabkan karena infeksi dari paru. Penyakit jantung menyebabkan terjadinya demam dengan mekanisme peningkatan metabolisme (hipermetabolisme) yaitu melalui peningkatan kerja dari miokardium dan respirasi, serta ekskresi ketokolammin yang berlebihan. ${ }^{15}$ Salah satu penyakit yang menyebabkan tumpang tindihnya gejala khas gagal jantung ialah sepsis neonatorum yang dapat menimbulkan gejala demam, distres pernapasan, sianosis, apneu, dan gejala tidak spesifik lainnya. ${ }^{16-17}$ Pneumonia pada bayi yang baru lahir juga dapat menimbulkan gejala yang mirip dengan gagal jantung seperti takikardia, retraksi, hipoksemia, dan grunting. ${ }^{18}$ Gejala sianosis pada gagal jantung oleh karena kurangnya perfusi pada jaringan tubuh karena kegagalan jantung memompa darah ke seluruh jaringan. ${ }^{19}$ Gejala sesak napas pada gagal jantung dapat terjadi disebabkan oleh adanya perubahan patologik pada denyut jantung dan saturasi oksigen sehingga terjadi kesulitan dan terhentinya napas. ${ }^{20}$

Hiperbilirubinemia fisiologik dapat terjadi pada seorang bayi baru lahir sampai minggu pertama kehidupan, bayi tampak ikterus, dan setelah itu ikterus tidak tampak lagi, tetapi bila ikterus tetap bertahan dan muncul setelah usia tersebut, maka dapat dicurigai adanya kelainan hati pada bayi. ${ }^{21}$ Ikterus pada sampel ditemukan karena kolestasis yang disebabkan oleh sepsis. Kolestasis yaitu terjadinya obstruksi pada aliran empedu dan menyebabkan terhambatnya cairan empedu. Keadaan ini dapat menyebabkan kondisi ikterus atau kekuningan pada kulit bayi. ${ }^{22}$ Walaupun kadang, keadaan ikterus dapat dipengaruhi oleh karena gagal jantung melalui terjadinya kongesti pasif pada hati atau hepatitis iskemik akut. $^{23,24}$

Pnemonia menempati urutan pertama penyakit penyerta pada pasien penyakit jantung bawaan di NICU RSUP Prof. Dr. R. D. Kandou Manado periode 2013-2017. Penderita kelainan PJB yang disertai peningkatan aliran darah ke paru yang bermakna seringkali menderita infeksi saluran napas bagian atas maupun pneumonia berulang. Infeksi tersebut dapat disebabkan oleh virus, bakteri atau mikroorganisme yang lain. Hal tersebut disebabkan antara lain karena saluran napas penderita menjadi basah sehingga fungsi dari toilet bronkial menjadi terganggu. ${ }^{25}$ Owayed et al. ${ }^{26}$ menyatakan bahwa PJB merupakan salah satu faktor risiko terjadinya pneumonia berulang pada anak. ${ }^{26}$

\section{SIMPULAN}

Berdasarkan hasil penelitian ini dapat disimpulkan bahwa jenis penyakit jantung bawaan yang sering ditemukan ialah penyakit jantung bawaan non sianotik dengan penyebab ASD, diikuti VSD, TOF, dan TAG. Jenis kelamin yang terbanyak ditemukan ialah laki-laki dan gelaja klinis yang sering ditemukan ialah sesak napas. Pneumonia merupakan diagnosis penyerta terbanyak. Status kempulangan pasien paling banyak dengan keadaan sembuh.

\section{DAFTAR PUSTAKA}

1. Primasari D. Perbedaan perkembangan pada anak dengan penyakit jantung bawaan sianotik dan non sianotik [Karya Tulis Ilmiah]. Semarang: Fakultas Kedokteran Universitas Diponegoro; 2012.

2. Bernier PL, Stefanescu A, Samoukovic G, Tchervenkov C. Pediatric cardiac surgery annual: the challenge of congenital heart disease worldwide. Epidemiologic and Demographic Facts. 2010;13(1): 26-34.

3. Wisnuwardhana M. Manfaat pemberian diet 
terhadap pertumbuhan pada anak dengan penyakit jantung bawaan [Disertasi]. Semarang: Universitas Diponegoro; 2006.

4. Burch M, Dedieu N. Congenital Heart Disease: the national society journals present selected research that has driven recent advances in clinical cardiology. 2012.

5. Roebiono PS. Diagnosis dan tatalaksana penyakit jantung bawaan [internet]. [cited 2018 Aug 15]. Jakarta. Available from: http://staff.ui.ac.id/system/files/ users/poppy.roebiono/material/diagnosi sdantatalaksanapjb-2.pdf

6. Maramis PP, Kaunang ED, Rompis J. Hubungan penyakit jantung bawaan dengan status gizi pada anak di RSUP Prof. Dr. R. D. Kandou Manado tahun 2009-2013. eCl. 2014;2(2).

7. Djer MM, Madiyono B. Tatalaksana penyakit jantung bawaan. Sari Pediatri. 2000; 2(3):155-62.

8. Rahman MA, Ontoseno T. Deteksi dini penyakit jantung bawaan pada neonatus: diagnosis dan saat rujukan. 2006. [cited 2018 Aug 15]. Available from: https://dokumen.tips/download/ link/deteksi-dini-penyakit-jantungbawaan-pada-neonatus

9. Wahab AS. Kardiologi Anak: Penyakit Jantung Kongenital yang Tidak Sianotik. Jakarta: EGC, 2009;p. 1-6.

10. Departemen Kesehatan RI. Pedoman Pelayanan Ruang Rawat Intensif. Jakarta: Direktorat Jendral Bina Pelayanan Medik, 2003.

11. Koniak-Griffin D, Martin LL, Reeder SJ. Maternity Nursing: Family, Newborn, and Women's Health Care (18th ed). (Afiyanti et al, penerjemah). USA: Lippicott William \& Wilkins Inc., 2003 (sumber asli diterbitkan tahun 1997).

12. Hermawan BJ, Hariyanto D, Aprilia D. Profil penyakit jantung bawaan di Instalasi Rawat Inap Anak RSUP Dr. M. Djamil Padang periode Januari 2013-Desember 2015. J Kes Andal. 2018;7(1):142-8.

13. Liu F, Yang Y, Xie X, Li X, Ma X, Fu Z. Prevalence of congenital heart disease in Xinjiang multi-ethnic region of China. Plos One. 2015;10(8).

14. Kinsey D, White PD. Fever in congestive heart failure. Arch Intern Med (Chic).
1940;65(1):163-170.

15. Lees MH, Bristow JD, Griswold HE, Olmsted RW. Relative hypermetabolism in infant with congenital heart disease and undernutrition. [cited 2018 Nov 28]. Available from: https://www. ncbi.nlm. nih.gov/pubmed/14320026.

16. Bonadio WA, Hennes H, Smith D, Ruffing $R$, Melzer-Lange $M$, Lye $P$, Isaacman D. Reliability of observation variables in distinguishing infectious outcome of febrile young infants. Pediatr Infect Dis J. 1993;12:111-4.

17. Gardes JS. Clinicopathologic approach to the diagnosis of neonatal sepsis. Clin Perinatol. 1991;18:361-81.

18. Bennett NJ. Pediatric pnemonia clinical presentation, Medscape. [cited 2018 Nov 28]. Available from: http://emedicine.medscape.com/article/ 967822-clinical.

19. Diller GP, Gatzoulis MA. Pulmonary vascular disease in adults with congenital heart disease. Circulation. 2007;115:1039-1050.

20. Aggarwal R, Sighal A, Deorari AK, Paul VK. Apneua in Newborn. Departemen of Pediatrica all India Institude of Medical Sciences Ansari Nagar. [cited 2018 Nov 28]. Avaiable from: http://www.newbornwhocc.org/pdf/Ap nea.pdf.

21. Porter ML Dennis BL. Hyperbilirubinemia in the Term Newborn. Am Fam Physician. 2002;65(4):599-607.

22. Herrine SK. Cholestasis. Merk Manuals. [cited 2018 Nov 28]. Available from: http://www.merckmanuals.com/home/li ver-and-gallbladder-disorders/ manifestations-of-liver-disease/ cholestasis.

23. Van Lingen R, Warshow U, Dalton HR, Hussaini SH. Jaundice as a presentation of heart failure. J R Soc Med. 2005 ;98(8):357-9.

24. Agata ID, Balistreri WF. Evaluation of liver disease in the pediatric patient. [cited 2018 Nov 28]. Avaiable from: http://www.columbia.edu/itc/hs/nursing /m6638/2003_2/session03/liver_disease .pdf. Pada tanggal 28 November 2018.

25. Hasan R, Alatas H. Buku Kuliah Ilmu Kesehatan Anak. Jakarta: Bagian Ilmu Kesehatan Anak Fakultas Kedokteran Universitas Indonesia, 1991. 
26. Owayed AF, Campbell DM, Wang EE.

Underlying causes of recurrent pneumonia in children. Arch Pediatr Adolesc Med. 2000:190-4. 